\title{
PENGARUH PRODUK DOMESTIK BRUTO DAN SBI TERHADAP PENERIMAAN PAJAK DI INDONESIA
}

\author{
Rahmanta \\ Departemen Agribisnis, Fakultas Pertanian USU \\ Telp. 081319035250, E-Mail : $\underline{\text { rahmantaginting@yahoo.com }}$
}

\begin{abstract}
The research to analyse effect net domestic product and $S B I$ on tax revenue in Indonesia with independent variables net domestic product and SBI also dependent variables tax revenue. Data is a time series between 1981 - 2010 with ordinary least square (OLS) and the model of formula used is multiply linier regression. The research result shows that net domestic product gives a positive effect and significant on tax revenue in Indonesia on 99\% level. While SBI has a negative effect and significant on tax revenue in Indonesia on $90 \%$ level.
\end{abstract}

Key words: Net Domestic Product, Indonesia Bank Sertificate and Tax Revenue

\section{PENDAHULUAN}

D alam struktur penerimaan Negara perpajakan masih merupakan primadona dan komponen terbesar dalam negeri untuk menopang pembiayaan operasional pemerintahan dan pembangunan. Di samping mampu menyediakan sumber dana bagi pembiayaan berbagai proyek penanggulangan dampak krisis ekonomi, penerimaan perpajakan juga dapat mencegah terjadinya pembengkakan defisit anggaran. Pajak tidak hanya dinikmati oleh pembayar pajak saja, tapi untuk kepentingan seluruh rakyat demi tercapainya pemerataan kesejahteraan di Indonesia.

Pada saat ini pajak merupakan sumber pendapatan suatu negara, pajak bagi negara dapat dilihat dari peran utama pajak sebagai instrumen utama kebijakan fiskal dimana kebijakan fiskal sangat penting untuk mengendalikan pertumbuhan ekonomi.Penerimaan pajak memiliki peranan yang strategis dalam menunjang operasi fiskal pemerintah. Pajak disamping sebagai sumber penerimaan utama negara (budgetary) juga mempunyai fungsi sebagai alat untuk mengatur (regulatory) dan mengawasi kegiatan-kegiatan swasta dalam perekonomian. Penerimaan pajak dapat berasal dari pajak penghasilan, pajak pertambahan nilai, pajak bumi bangunan, maupun pajak-pajak lainnya. Di sisi lain, penerimaan pajak dapat berupa penerimaan pajak dalam negeri dan penerimaan pajak perdagangan internasional. Indonesia 
sebagai negara di dunia tidak terlepas dari dunia internasional yang menyebabkan aspek perpajakan yang lebih kompleks yang membutuhkan perhatian serius dari pemerintah untuk mengatur kebijakan dan harmonisasi dunia internasional.

Suku bunga adalah biaya yang harus di bayar oleh pemimjam atas pinjaman yang diterima dan merupakan imbalan bagi pemberi pinjaman atas investasinya. Suku bunga mempengaruhi keputusan individu terhadap pilihan membelanjakan uang lebih banyak atau menyimpan uangnya dalam bentuk tabungan. Suku bunga yang tinggi di satu sisi, akan meningkatkan hasrat masyarakat untuk menabung sehingga jumlah dana perbankan akan meningkat, di lain pihak minat masyarakat untuk melakukan investasi akan menurun. Sebaliknya tingkat suku bunga yang rendah akan mendorong minat masyarakat untuk melakukan investasi, membuka usaha atau kegiatan sejenisnya yang akan dapat meningkatkan penerimaan pajak, khususnya pajak pertambahan nilai dari produk yang dihasilkan atau bahan baku yang digunakan.

Suatu negara dapat dikatakan mengalami pertumbuhan ekonomi yang positif apabila kuantitas barang dan jasa yang dihasilkan negara tersebut mengalami kenaikan. Namun demikian dalam kenyataannya sangat sulit untuk mengetahui berapa jumlah barang dan jasa yang dihasilkan oleh suatu negara dalam kurun waktu tertentu. Oleh karena itu untuk mengukur pertumbuhan ekonomi atau pertumbuhan output dilakukan dengan menggunakan perubahan nilai moneternya (uang) yang tercermin dalam Produk Domestik Bruto. Semakin tinggi nilai Produk Domestik Bruto maka pendapatan per kapita masyarakat juga meningkat sehingga penerimaan pajak akan meningkat melalui penerimaan pajak penghasilan dan pajak lainnya.

Untuk penentuan penerimaan pajak memerlukan suatu perencanaan yang wajar dan obyektif dalam arti tidak hanya berorientasi pada pencapaian penerimaan semata, akan tetapi juga harus melihat faktor-faktor ekonomi makro secara eksternal yang dapat mempengaruhi di dalam penentuan suatu target penerimaan pajak. Oleh karena itu perlu dikaji faktor-faktor manakah yang dapat mempengaruhi penerimaan pajak sehingga target yang dialokasikannya dapat teralisasi dengan baik sesuai dengan potensi yang ada. Dari uraian tersebut, penulis membahas pengaruh produk domestik bruto dan tingkat suku bunga SBI terhadap penerimaan pajak di Indonesia. Yang menjadi masalah dalam penelitian ini adalah: (1) apakah Produk Domestik Bruto berpengaruh terhadap penerimaan pajak di Indonesia?,dan (2) apakah tingkat suku bunga SBI berpengaruh terhadap penerimaan pajak di Indonesia ?

Pajak adalah suatu pungutan yang merupakan hak prerogatif pemerintah dimana pungutan tersebut didasarkan pada Undang-undang dan pemungutannya dapat dipaksakan kepada subyek dan obyek pajak.Penerimaan pajak negara terdiri dari penerimaan dalam negeri pemerintah dan hibah. Penerimaan dalam negeri pemerintah terdiri atas : (a) pajak penghasilan, (b) pajak pertambahan nilai barang dan jasa dan pajak penjualan atas barang mewah, (c) pajak bumi dan bangunan, (d) bea perolehan hak atas tanah dan bangunan, (e) cukai, dan (d) pajak lainnya. Peranan penerimaan perpajakan sebagai salah satu sumber penting dalam pembiayaan Negara akan terus ditingkatkan dengan melakukan berbagai evaluasi dan kebijakan penyempurnaan. Hal tersebut dimaksudkan agar pelaksanaan sistem perpajakan dapat lebih efektif dan efisien sejalan dengan perkembangan globalisasi yang menuntut daya saing yang tinggi dengan negara lain. Dengan demikian diharapkan prinsip-prinsip 
perpajakan yang sehat seperti : persamaan, kesederhanaan dan keadilan dapat tercapai sehingga tidak hanya berdampak terhadap peningkatan kapasitas fiskal, melainkan juga terhadap perkembangan kondisi ekonomi makro Indonesia.

Menurut Supramono dan Damayanti (2005) fungsi pajak adalah sebagai berikut: (1) Fungsi penerimaan (budget) yaitu fungsi sebagai sumber dana bagi pemerintah untuk membiayai pengeluaran-pengeluaran, (2) Fungsi mengatur (regulator) yaitu fungsi untuk mengatur atau mengeluarkan kebijakan-kebijakan pemerintah dari sudut sosial dan ekonomi.

Berdasarkan kewenangan dalam pemungutannya, pajak dapat digolongkan menjadi pajak pusat dan pajak daerah. Pajak pusat adalah jenis pajak yang dipungut oleh pemerintah pusat, diantaranya pajak penghasilan, pajak pertambahan nilai, pajak bumi dan bangunan, bea perolehan hak atas tanah dan bangunan, bea materai, bea masuk, cukai dan pungutan ekspor. Sedangkan pajak daerah dipungut oleh pemerintah daerah, baik pemerintah daerah provinsi dan pajak daerah kabupaten/kota, diantaranya pajak kenderaan bermotor, bea balik nama kenderaan bermotor, pajak hiburan, pajak restoran, dan pajak lainnya.

Saefuddin (2008) menyimpulkan bahwa jumlah pengusaha kena pajak mempunyai pengaruh positif dan signifikan terhadap penerimaan pajak pertambahan nilai di provinsi Sumatera Utara. Sedangkan inflasi tahun sebelumnya mempunyai pengaruh negatif dan signifikan terhadap penerimaan pajak pertambahan nilai di Provinsi Sumatera Utara, dan pertumbuhan ekonomi mempunyai pengaruh positif dan signikan serta terbesar yang mempengaruhi penerimaan pajak pertambahan nilai.

Nasution (2003) yang merupakan penelitian ex post facto yang merupakan penelitian dari peristiwa yang telah terjadi dan kemudian diruntut mengenai faktorfaktor yang mempengaruhi dari berbagai sumber. Hasil penelitian menunjukkan bahwa potensi dan pertumbuhan penerimaan pajak penghasilan selama dasawarsa 1990-2000 diantaranya dipengaruhi baik secara langsung maupun tidak langsung oleh faktor produk domestik bruto, jumlah wajib pajak, dan jumlah kantor pelayanan pajak yang tersebar di seluruh Indonesia.

\section{METODOLOGI}

Penelitian ini memfokuskan pada produk domestik bruto dan tingkat suku bunga SBI terhadap penerimaan pajak di Indonesia, selama kurun waktu antara tahun 1981 - 2010. Penelitian ini menggunakan dasar pertimbangan bahwa struktur penerimaan pajak masih didominasi oleh kontribusi produk domestik bruto dan tingkat suku bunga SBI.

Data yang dipergunakan dalam penelitian ini adalah data time series (runtut waktu) yang merupakan data sekunder. Data sekunder merupakan data primer yang telah diolah dan disajikan ke dalam tabel dan bentuk lain. Sedangkan data time series merupakan sekumpulan deret data dari suatu fenomena tertentu yang didapat dalam interval waktu tertentu misalnya bulan dan tahun.

Metode analisis yang digunakan dalam penelitian ini adalah model regresi linier berganda. Alat analisis untuk mengolah data adalah dengan menggunakan 
program Eviews versi 6. Untuk mengidentifikasi variabel bebas dan variabel terikat digunakan fungsi persamaan sebagai berikut :

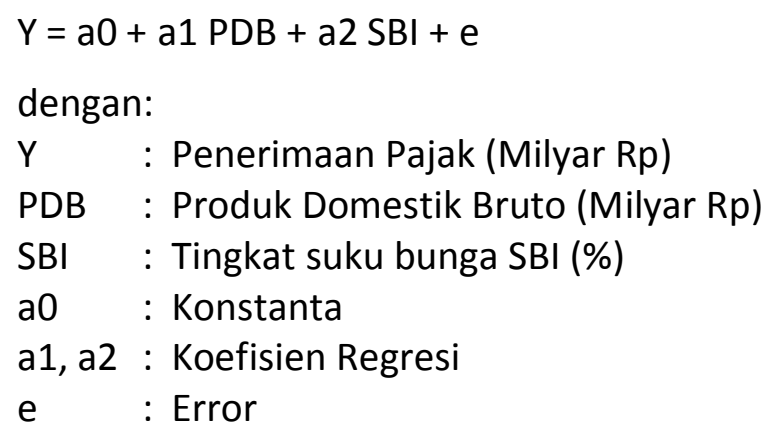

Estimasi terhadap model dilakukan dengan mengguanakan metode yang tersedia pada program statistik yaitu Eviews versi 6 . Koefisien yang dihasilkan dapat dilihat pada output regresi berdasarkan data yang di analisis untuk kemudian diinterpretasikan serta dilihat siginifikansi tiap variabel yang diteliti. $R^{2}$ (koefisien determinasi) bertujuan untuk mengetahui kekuatan variabel bebas (independent variable) menjelaskan variabel terikat (dependent variabel).Uji serempak (F-test), dimaksudkan untuk mengetahui signifikansi statistik koefisien regresi secara serempak.

Uji parsial (t-test), dimaksudkan untuk mengetahui signifikansi statistik koefisien regresi secara parsial. Jika $\mathrm{t}$ statistik $>\mathrm{t}$ tabel maka $\mathrm{HO}$ ditolak dan $\mathrm{H} 1$ diterima. Signifikansi koefisien regresi secara parsial dapat juga diamati dari nilai probabilitas ( $p$-value). Apabila Nilai probabilitas lebih kecil dari $\alpha$, maka Ho ditolak dan sebaliknya apabila nilai probabilitas lebih besar dari $\alpha$, maka Ho diterima.

Setelah dilakukan pengujian regresi, maka dilakukan evaluasi. Evaluasi ini dimaksudkan untuk mengetahui apakah penggunaan model regresi linier berganda dalam menganalisis telah memenuhi asumsi klasik yang dipersyaratkan. Asumsi klasik yang digunakan dalam penelitian ini, meliputi : (a) uji autokorelasi, (b) uji normalitas, (c) uji linieritas, dan (d) uji multikolinieritas.

Untuk memudahkan pemahaman terhadap istilah dan variabel yang digunakan dalam penelitian ini perlu diberikan batasan operasinal sebagai berikut: (1) Pajak adalah penerimaan negara dari sektor pajak yang terdiri dari pajak dalam negeri dan pajak internasional dalam satuan Milyar Rupiah per tahun, (2) Produk Domestik Bruto (PDB) adalah produk domestik bruto Indonesia berdasarkan harga konstan di ukur dalam Milyar Rupiah per tahun, (3) Tingkat suku bunga SBI adalah suku bunga surat berharga yang dikeluarkan Bank Indonesia yang di ukur dalam persen per tahun.

\section{HASIL DAN PEMBAHASAN}

Untuk mengetahui pengaruh produk domestik bruto dan tingkat suku bunga SBI terhadap penerimaan pajak maka dilakukan estimasi dengan model regresi linier berganda. Hasil estimasi dari pengolahan data sebagai berikut :

$$
Y=10801,36+0,1229 \text { PDB }-1208,753 \text { SBI }
$$




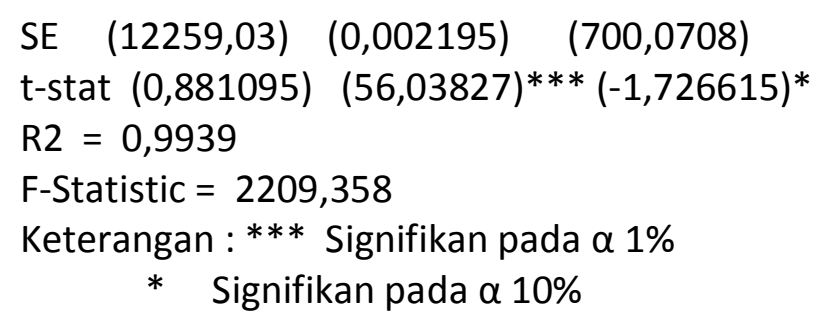

Berdasarkan hasil estimasi di atas dapat menunjukkan bahwa R2 = 0.9939 yang bermakna bahwa variasi produk domestik bruto dan tingkat suku bunga SBI mampu menjelaskan variasi penerimaan pajak sebesar 99,39 persen dan sisanya 0,61 persen dijelaskan oleh variabel lain yang tidak dimasukkan dalam model estimasi.

Berdasarkan hasil uji simultan (serempak) yang dilakukan melihat signifikansi secara bersama-sama variabel bebas dalam mempengaruhi variabel terikat. Dari estimasi tersebut diperoleh nilai prob (F-Statistik) sebesar $0.000<\alpha \quad 0,05$ atau $\mathrm{F}$ hitung $(2209,358)>\mathrm{F}$ tabel $(5,49)$ yang berarti variabel produk domestik bruto dan tingkat suku bunga SBI secara bersama-sama dapat mempengaruhi penerimaan pajak dengan tingkat keyakinan 99 persen.Pengujian secara partial dilakukan dengan membandingkan nilai t- hitung dengan nilai t-tabel. Selain itu juga dilihat berdasarkan nilai signifikansi (sig) pada hasil estimasi. Berdasarkan uji partial (Uji t-statistik) dapat diketahui variabel yang berpengaruh secara signifikan terhadap penerimaan pajak di Indoensia.

\section{PRODUK DOMESTIK BRUTO TERHADAP PENERIMAAN PAJAK}

Hasil estimasi di atas, variabel Produk Domestik Bruto memberikan pengaruh yang positif secara statistik terhadap penerimaan pajak di Indoensia. Nilai koefisien regresi untuk nilai Produk Domestik Bruto sebesar 0,1229 mengandung arti bahwa setiap terjadi peningkatan satu milyar rupiah nilai Produk Domestik Bruto maka penerimaan pajak meningkat sebesar 0,1229 milyar rupiah, ceteris paribus. Hasil pengolahan data ini sesuai dengan hipotesis yang menyatakan bahwa terdapat pengaruh yang positif variabel nilai Produk Domestik Bruto terhadap penerimaan pajak di Indonesia.

Di samping itu, dari hasil pengujian t-statistiknya menunjukkan bahwa nilai tstatistik sebesar 56,038 ternyata lebih besar dari nilai t-tabel sebesar 2,77. Hal ini menunjukkan bahwa variabel nilai Produk Domestik Bruto memberikan pengaruh yang signifikan terhadap jumlah penerimaan pajak di Indonesia pada tingkat kepercayaan sebesar 99 persen.

Berdasarkan hasil olahan data ini menunjukkan bahwa nilai Produk Domestik Bruto masih berperan dalam meningkatkan jumlah penerimaan pajak di Indoensia. Hal ini terlihat bahwa nilai Produk Domestik Bruto yang terjadi di Indoensia selama kurun waktu 1981-2010 terus mengalami peningkatan seiring peningkatan jumlah penerimaan pajak. Dengan demikian, hasil studi ini dapat dijadikan sebagai bahan masukan bagi para pengambil kebijakan khususnya di Indoensia, untuk dapat menjadikan nilai Produk Domestik Bruto sebagai stimulus dalam meningkatkan nilai penerimaan pajak ke depan. Peningkatan Produk Domestik Bruto dalam hal ini adalah peningkatan pertumbuhan ekonomi di Indonesia untuk kemudian meningkatkan 
pendapatan per kapita. Peningkatan pendapatan per kapita akan selalu diikuti dengan peningkatan membayar pajak, sehingga pada akhirnya akan menambah jumlah penerimaan pajak bagi negara.

\section{TINGKAT SUKU BUNGA SBI TERHADAP PENERIMAAN PAJAK}

Hasil estimasi di atas, variabel tingkat suku bunga SBI memberikan pengaruh yang negatif secara statistik terhadap penerimaan pajak di Indoensia. Nilai koefisien regresi untuk nilai tingkat suku bunga SBI sebesar 1208,753 mengandung arti bahwa setiap terjadi peningkatan satu persen tingkat suku bunga SBI maka penerimaan pajak akan menurun sebesar 1208,753 milyar rupiah, ceteris paribus. Hasil pengolahan data ini sesuai dengan hipotesis yang menyatakan bahwa terdapat pengaruh yang negatif variabel tingkat suku bunga SBI terhadap penerimaan pajak di Indonesia.

Di samping itu, dari hasil pengujian t-statistiknya menunjukkan bahwa nilai tstatistik sebesar $-1,7266$ ternyata secara nilai absolut lebih besar dari nilai t-tabel pada tingkat kesalahan 10 persen yaitu sebesar 1,703. Hal ini menunjukkan bahwa variabel tingkat suku bunga SBI memberikan pengaruh yang signifikan terhadap jumlah penerimaan pajak di Indonesia pada tingkat kepercayaan sebesar 90 persen.

Berdasarkan hasil olahan data ini menunjukkan bahwa tingkat suku bunga SBI berperan dalam mempengaruhi jumlah penerimaan pajak di Indoensia. Hal ini terlihat bahwa nilai tingkat suku bunga SBI yang terjadi di Indoensia selama kurun waktu 19812010 terus mengalami fluktuasi. Dengan demikian, hasil studi ini dapat dijadikan sebagai bahan masukan bagi para pengambil kebijakan khususnya di Indoensia, untuk dapat menjadikan tingkat suku bunga SBI dalam kondisi yang terjaga atau adanya penurunan nilai tingkat suku bunga SBI agar dapat meningkatkan nilai penerimaan pajak ke depan.

\section{UJI PENYIMPANGAN ASUMSI KLASIK UJI AUTOKORELASI (UJI LM TEST)}

Autokorelasi didefinisikan sebagai korelasi antara anggota serangkaian observasi yang diurut menurut waktu. Dalam model regresi linier klasik mengasumsikan bahwa autokorelasi seperti itu tidak terdapat dalam disturbance. Dengan menggunakan lambang $E(\mu \mathrm{i}, \mu \mathrm{j})=0 ; \mathrm{i}=\mathrm{j}$ Secara sederhana dikatakan bahwa model klasik mengasumsi unsur gangguan yang berhubungan dengan observasi tidak dipengaruhi oleh unsur disturbance atau gangguan yang berhubungan dengan pengamatan lain/manapun. Untuk mendeteksi adanya autokorelasi dalam model penelitian ini dilakukan uji Lagrange Multiplier Test (LM Test).

Untuk mendiagnosa ada tidaknya autokorelasi dapat dilakukan dengan menggunakan Lagrange Multiplier Test (LM-Test). Uji non autokorelasi adalah evaluasi korelasi serial dari disturbance term error dengan hipotesis nol disturbance term error adalah non autokorelasi. Pengujian asumsi non autokorelasi menggunakan BreuschGodfrey $[\mathrm{BG}]$ Test atau LM Test. $B G-$ statistic $=[T-p] \times R^{2}$, di mana $\mathrm{p}=$ panjang time lag dari disturbance term error dan juga merupakan derajat bebas Tabel Distribusi

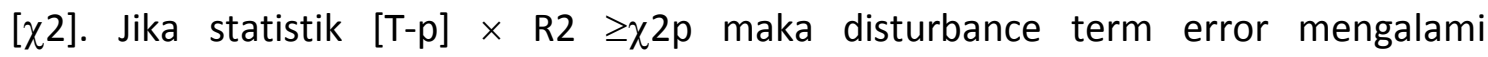


autokorelasi, sebaliknya jika [T-p] $\times \mathrm{R} 2<\chi 2 \mathrm{p}$ maka disturbance term error tidak mengalami autokorelasi. Hasil pengujian autokorelasi ditunjukkan pada Tabel 1.

Tabel 1.Uji Autokorelasi pada Hasil Estimasi

\begin{tabular}{|c|c|c|c|c|}
\hline $\begin{array}{c}\text { Jenis } \\
\text { Uji }\end{array}$ & Alat Uji & $\begin{array}{c}\text { Nilai Hitung } \\
\text { Obs* } R^{2}\end{array}$ & Nilai Tabel $X^{2}$ & Kesimpulan \\
\hline $\begin{array}{c}\text { Autoko } \\
\text { relasi }\end{array}$ & LM Test & 4.138731 & 9,21 & $\begin{array}{c}\text { Tidak ada autokorelasi } \\
\text { dalam model }\end{array}$ \\
\hline
\end{tabular}

Sumber : Hasil Pengolahan Data

Pada Tabel 1 ini diperoleh besarnya nilai LM Test sebesar 4.138731 dan bila dibandingkan dengan nilai $X^{2}$ tabel sebesar 9,21 pada taraf 99\%, maka dapat disimpulkan bahwa nilai LM Test lebih kecil dari nilai $X^{2}$ table (obs $R^{2} 4,138731<X^{2}$ tabel 9,21) dengan demikian tidak ada autokorelasi pada data penelitian ini.

\section{UJI NORMALITAS}

Untuk mendeteksi apakah residualnya berdistribusi normal atau tidak dengan membandingkan nilai Jarque Bera (JB) dengan X2 tabel, yaitu: (1) Jika nilai JB > X2 tabel, maka residualnya berdistribusi tidak normal, (2) Jika nilai JB $<$ X2 tabel, maka residualnya berdistribusi normal.Analisis Hasil Output, bahwa nilai JB sebesar 6,3179. Karena 6,3179 $<9,21$ maka dapat disimpulkan bahwa residual berdistribusi normal.

\section{UJI LINIERITAS (RAMSEY RESET TEST)}

Uji ini merupakan uji yang sangat populer dikembangkan oleh Ramsey di tahun 1969, uji ini dilakukan berkaitan dengan masalah spesifikasi kesalahan yakni apakah kesalahan spesifikasi model yang kita gunakan sudah benar atau tidak, sehingga melalui uji linieritas ini dapat diketahui bentuk model empiris (berbentuk linier, kuadrat atau kubik) dan menguji variabel yang relevan untuk dimasukkan dalam model empiris. Berikut ini dapat dilihat hasil estimasi dari Ramsey test seperti pada Tabel 2.

Tabel 2. Hasil Estimasi Ramsey Test

\begin{tabular}{|l|l|l|l|}
\hline F-statistic & 0,049114 & Probability & 0.8263 \\
\hline Log likelihood ratio & 0,056617 & Probability & 0.8119 \\
\hline
\end{tabular}

Sumber : Hasil Pengolahan Data

Berdasarkan hasil estimasi Ramsey test di atas, diperoleh besarnya nilai $\mathrm{F}$ hitung statistik sebesar 0,049114 yang berarti nilai F-hitung lebih kecil dibandingkan nilai F-tabel sebesar 5,49 pada level signifikan 1 persen. Dengan demikian melalui Ramsey test ini dapat disimpulkan bahwa model yang digunakan dalam bentuk regresi linier berganda adalah model yang bersifat linier.

\section{UJI MULTIKOLINIERITAS}

Uji ini digunakan untuk menganalisis apakah ada hubungan linear di antara variabel-variabel bebas dalam model regresi. Apabila terjadi hubungan yang kuat di antara variabel bebas maka dikatakan terjadi multikolinieritas, dan sebaliknya tidak 
terjadi multikolinieritas.Persamaan (1) nilai R2 adalah sebesar 0.9939 selanjutnya disebut R21. Untuk persamaan (2) nilai R2 adalah sebesar 0.266057 selanjutnya disebut R22. Untuk persamaan (3) nilai R2 adalah sebesar 0.266057 selanjutnya disebut R23. Ketentuan:Bila nilai R21 > R22, R23, maka model tidak diketemukan adanya multikolinearitas. Bila nilai R21 < R22, R23, maka model diketemukan adanya multikolinearitas. Analisis Hasil Output, menunjukkan bahwa nilai R21 > R22, R23 maka dalam model tidak diketemukan adanya multikolinearitas.

\section{KESIMPULAN DAN SARAN}

\section{Kesimpulan}

Berdasarkan hasil dan pembahasan yang telah dilakukan di atas, maka dapat disimpulkan sebagai berikut:

1. Hasil estimasi menunjukkan bahwa $R^{2}=0.9939$ yang bermakna bahwa variasi produk domestik bruto dan tingkat suku bunga SBI mampu menjelaskan variasi penerimaan pajak sebesar 99,39 persen, dan sisanya 0,61 persen dijelaskan oleh variabel lain yang tidak dimasukkan dalam model estimasi.

2. Berdasarkan hasil uji parsial diperoleh bahwa produk domestik bruto berpengaruh positif dan signifikan terhadap penerimaan pajak, dan tingkat suku bunga SBI berpengaruh negatif dan signifkan terhadap penerimaan pajak.

\section{Saran}

Berdasarkan hasil penelitian dan kesimpulan di atas, maka dapat disarankan sebagai berikut :

1. Pemerintah Daerah dan Pusat agar lebih serius dalam meningkatkan pertumbuhan ekonomi melalui penyediaan sarana dan prasarana karena apabila peningkatan pertumbuhan ekonomi akan meningkatkan PDB sehingga akan meningkatkan penerimaan pajak oleh pemerintah.

2. Bagi peneliti-peneliti selanjutnya disarankan dapat menemukan variabelvariabel lain yang pengaruhnya lebih nyata dalam meningkatkan penerimaan pajak selain variabel yang sudah diujikan.

\section{DAFTAR PUSTAKA}

Gujarati, D.N., 1989. Basic Econometrics, 2nd ed., McGraw-Hill Company. New York. Kusmono, H. 2011. Analisis Determinan Penerimaan Pajak di Indonesia. Tesis Program Pascasarjana Magister Ekonomi Pembangunan USU. Medan.

Mankiw, N Gregory, 2003.Pengantar Ekonomi Makro, Edisi ketiga, Salemba Empat, Jakarta.

Nachrowi, Djalal. Nachrowi dan Usman, Hardius. 2002. Penggunaan Teknik Ekonometrika. Rajagrafindo Persada. Jakarta.

Nazir, M, 1998, Metodologi Penelitian Pembangunan Desa, Penerbit Bina Aksara, Jakarta. 
Nasution, C.S. 2003. Analisis Potensi dan Pertumbuhan Penerimaan Pajak Penghasilan (PPh) di Indonesia Periode : 1990 - 2000. Jurnal Kajian Ekonomi dan Keuangan. Volume 7, Nomor 2. Jakarta.

Saefuddin, 2008. Analisis Faktor-faktor Yang Mempengaruhi Pajak Pertambahan Nilai Di Sumatera Utara. Tesis Program Pascasarjana Magister Ekonomi Pembangunan USU. Medan.

Soemitro, dkk. 2004. Azaz dan Dasar Perpajakan. Penerbit PT. Refika Aditama, Bandung.

Suparmoko. 2000. Keuangan Negara Dalam Teori dan Praktek. Edisi 5, BPFE. Yogyakarta.

Supramono dan Damayanti, T.W. 2005. Perpajakan Indonesia : Mekanisme dan Perhitungannya. Penerbit Andi, Yogyakarta.

Todaro, Michael., P. 2003. Economic Development. Eight Edition. Pearson Education Limited. Eidenburg Gate, Harlow, Essex, England. 